\title{
Seasonal changes of perlite-peat substrate properties in seedlings grown in different sized container trays
}

\author{
Mariusz Kormanek ${ }^{1}$ (D) . Stanisław Małek ${ }^{2}$. Jacek Banach ${ }^{2} \cdot$ Grzegorz Durło $^{3}$. \\ Krystyna Jagiełło-Leńczuk ${ }^{2} \cdot$ Katarzyna Dudek $^{2}$
}

Received: 9 November 2019 / Accepted: 9 May 2020 / Published online: 20 May 2020

(c) The Author(s) 2020

\begin{abstract}
Cultivation of seedlings in trays requires the use of specifically developed substrates. This study presents the results of the analyses of selected physical and mechanical parameters of a peat-perlite substrate, in which seedlings of the Scots pine (Pinus sylvestris L.), Norway spruce (Picea abies (L.) H. Karst), European beech (Fagus sylvatica L.), and pedunculate oak (Quercus robur L.) were grown during a production season. For each species, the substrate parameters changed throughout the production season, substrate dry weight decreased, whereas its compactness increased with time. Independent of the species, the bulk density and total porosity of the substrate changed or deviated from the optimum range, although the values of porosity were close to maximum and those of density were close to the minimum. In certain periods in the V265 trays with beech and oak seedlings, the substrate was characterized by very low water capacity and excessive air capacity. Compactness measured with a cone penetrometer showed, that this parameter might be used for monitoring the substrate properties.
\end{abstract}

Keywords Compactness · Nursery tray $\cdot$ Penetrometer $\cdot$ Physical and mechanical parameters $\cdot$ Seedling

\section{Introduction}

Cultivation of seedlings in container nurseries is influenced by several factors, some of which are independent or partially independent of the nurseryman while others can be modified. Among them, the environmental conditions in which the seedlings grow cannot be modified to a large extent (Lea-Cox et al. 2009; Durło et al. 2018), whereas the quality of seeds (Landis et al. 2010; Kaliniewicz and Tylek 2018), organization of procedures

Mariusz Kormanek

rlkorma@cyf-kr.edu.pl

1 Department of Forest Utilization, Engineering and Forest Techniques, Faculty of Forestry,

University of Agriculture in Krakow, Al. 29 Listopada 46, 31-425 Kraków, Poland

2 Department of Ecology and Sylviculture, Faculty of Forestry, University of Agriculture in Krakow, Al. 29 Listopada 46, 31-425 Kraków, Poland

3 NaviGate LLC, Wadowicka 8a, 30-415 Kraków, Poland 
and the methods of production (Wesoły and Hauke 2009), selection of trays (Landis 1990; Ruter and vad de Werken 1991; Tian et al. 2017; Sun et al. 2018) and substrates for the cultivation of a given species (Nkongolo and Caron 1999; Abad et al. 2005; Heiskanen and Rikola 1998; Buck and Evans 2010; Bakry et al. 2013; Fornes and Belda 2019) can be modified to obtain better results while carrying out proper irrigation and fertilization (Mathers et al. 2005; Beeson 2006; Dumroese et al. 2015; Stowe et al. 2010). A specifically composed substrate is one of the important elements of tray cultivation in the nursery; in particular, its physical and mechanical properties influence the growth and quality of the produced seedlings (Argo 1998; Bilderback et al. 2005; Banach et al. 2013). The air/water relationships of a substrate and its chemical composition must be analyzed for achieving successful cultivation. The air and water-holding capacity and thermal conditions of the substrate determine the amount of water to be supplied, as well as the required irrigation frequency (Leciejewski 2011). According to Cabrera and Johnson (2014), a desirable substrate is the one that gets moistened immediately upon sprinkling irrigation and retains at least $10 \%$ or more of air volume after sprinkling. The optimal substrate parameters for achieving successful tray cultivation are as presented in Table 1 . The cited ranges of parameters are relatively wide, and the methodology of measurement is not always unambiguous, which results in a significant issue with the appropriate controlling of substrate parameters during the cultivation of seedlings (Paquet et al. 1993; Cook et al. 2004). The air/water relationships of the substrate may also change with time as a result of gradual, compaction of the soil caused by frequent irrigation (Oleszczuk et al. 2003). Substrate compaction and its settlement is higher if the layer of the substrate is thicker, its composition, and the intensity of irrigation is higher. Changes in these properties may also stem from the gradual shift of finer particles of the substrate in the tray cell from the upper level to the bottom level. Decomposition of the organic matter occurs in a similar direction, whereas the reverse (favorable) effect is exhibited by the growth of the root system of seedlings (Paquet et al. 1993; Allaire et al. 1996; Strojny 2003; Mathers et al. 2005; Evans and Gachukia 2007). Roots of seedlings growing in a substrate are exposed to more stress compared to those growing in mineral soil (Kormanek et al. 2015a, b). In a typical production tray, a plant is capable of utilizing the entire amount of available water within 2 days of growth. If a peat substrate is sprinkled with small volumes of water, the entire volume may only remain in the upper portion of the substrate, whereas the lower portion remains dry (Landis 1990; Luna et al. 2009; Cabrera and Johnson 2014). In addition, the amount of water absorbed by the substrate may be reduced by the interception by foliage. The intercepted water is lost by evaporation, especially when plants are irrigated with a very fine mist of water and the evaporation rate is high (Heiskanen 1995). If the physical parameters of a substrate that determine its usability for seedling cultivation are unsuitable, they are difficult to modify (Allaire et al. 1996). Unfortunately, only limited data are available in the literature on the seasonal changes of the physical and mechanical properties of peat substrate used in tray nurseries (Michel 2009). Moreover, the available literature lacks information on the compactness measured with a penetrometer, which is an important physicomechanical parameter frequently used to assess peat substrates, in both field and laboratory conditions (Boylan et al. 2011; Hayashi and Hayashi 2016). This parameter could also be used to characterize the peat-based substrates.

The objective of the present study was to analyze the changes occurring during the growing season in the selected physicomechanical parameters of peat-perlite substrate in nursery trays in which seedlings of the Scots pine (Pinus sylvestris L.), Norway spruce (Picea abies (L.) H. Karst), European beech (Fagus sylvatica L.), and pedunculate oak (Quercus robur L.) were grown. During the research, it was assumed that no differences 


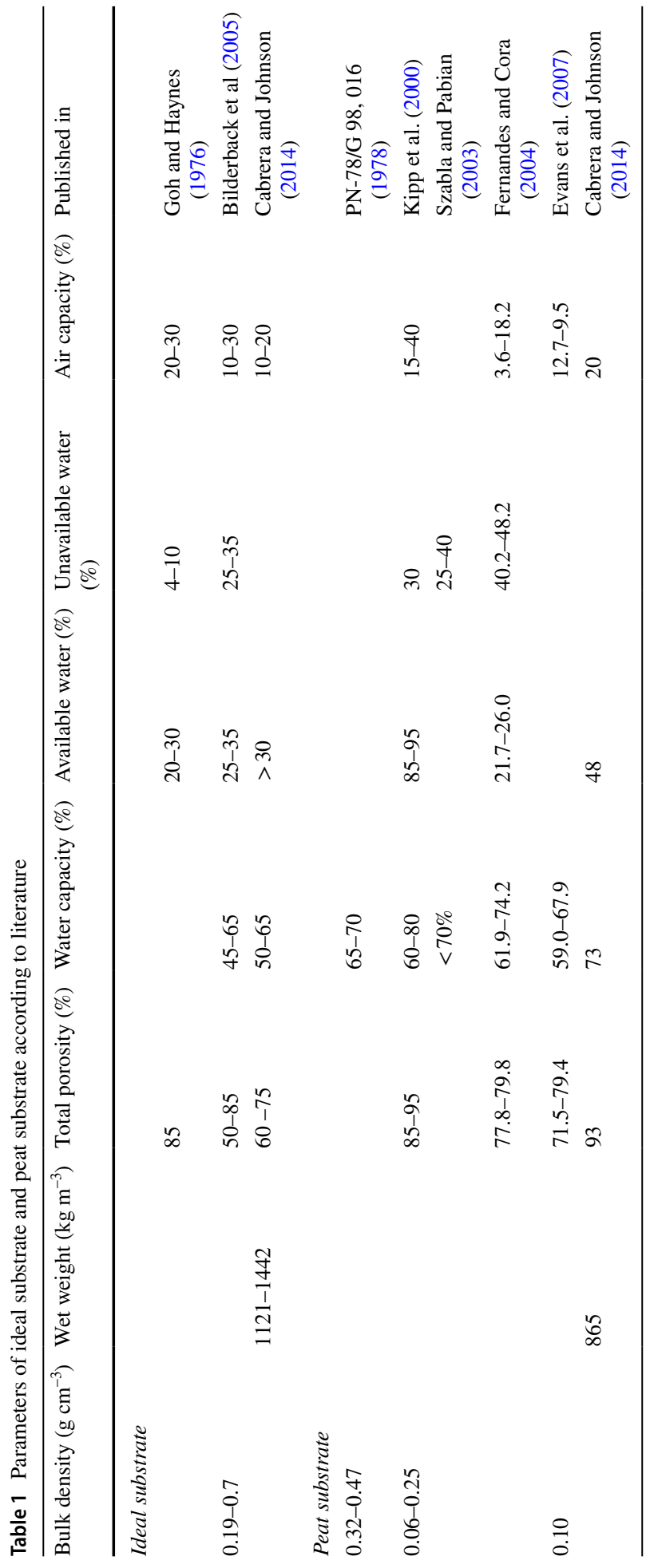


existed between the values of the analyzed physicomechanical parameters of the substrate obtained on individual dates of sample collection as well as between the individual species.

\section{Materials and methods}

The nursery trays were filled with peat-perlite substrate (95:5\%) on an automated line produced by BCC AB, in the Nursery Farm "Nędza" in Poland (50¹0'04.8" N 18 18'57.7" E).

Throughout the growing season, the seedlings were irrigated and supplied with foliar Bioekor $\left(\mathrm{NO}_{3}-\mathrm{N} 1.0 \%, \mathrm{NH}_{2}-\mathrm{N} 7.5 \%, \mathrm{P}_{2} \mathrm{O}_{5} 3.0 \%, \mathrm{~K}_{2} \mathrm{O} 4.4 \%\right.$, and microelements: $\mathrm{Fe}, \mathrm{B}, \mathrm{Cu}$, $\mathrm{Mn}, \mathrm{Mo}$, and $\mathrm{Zn})$ and Floralesad $\left(\mathrm{NO}_{3}-\mathrm{N} 1.2 \%, \mathrm{NH}_{2}-\mathrm{N} 8.0 \%, \mathrm{P}_{2} \mathrm{O}_{5} 3.5 \%, \mathrm{~K}_{2} \mathrm{O} 5.0 \%, \mathrm{MgO}\right.$ $0.5 \%$, and microelements: $\mathrm{S}, \mathrm{Fe}, \mathrm{B}, \mathrm{Cu}, \mathrm{Mn}, \mathrm{Mo}$, and $\mathrm{Zn}$ ) fertilizers (Table 2).

Sprinkling and fertilization in the vegetation hall were performed with a BCC GB-T1 boom, whereas in the open production fields the procedures were carried out with a BCC HAB T1 boom. In the case of spruce, the Osmocote fertilizer was also used at a dose of $2.5 \mathrm{~kg} \mathrm{~m}^{-3}$ of the substrate. During the growing season from 15 May to 16 October, on 12 dates (at 2-week intervals), one tray was collected in the nursery per species. Subsequently, physical parameters (bulk density, total porosity, air capacity, water capacity) of the substrate were determined in four randomly selected cells, whereas in all the remaining ones the substrate compactness co $(\mathrm{Pa})$ was measured using the Eijkelkamp type IB 0606 penetrometer with a cone diameter of 0.5 or 0.33 in. $(1.27$ or $0.78 \mathrm{~cm})$ (Ferree et al. 2004). The larger cone was used for measurement in the cells of the V265 tray and for a small root system, whereas the smaller one was utilized to measure cells with a smaller volume (V120SS) and in the case of the heavily developed root system in the cells of the V265 tray. Following the analysis of the physical parameters of the substrate, the degree to which the cells were filled with the substrate was measured $( \pm 1 \mathrm{~mm})$. Subsequently, the substrate was moistened by immersing the tray in containers with water (for $12 \mathrm{~h}$ ). After substrate moistening, the trays were removed from water and the so-called gravitational loose-bound water was drained from the cells for approximately 20 min (Maciak and Liwski 1996), and the trays were weighted on a BTA2100D analytical balance $( \pm 0.01 \mathrm{~g})$. Subsequently, the seedlings were carefully removed from the trays and the moistened substrate was manually separated and weighted. The substrate was dried for $48 \mathrm{~h}$ (first $24 \mathrm{~h}$ at a temperature of $65^{\circ} \mathrm{C}$ and the next $24 \mathrm{~h}$ at a temperature of $105^{\circ} \mathrm{C}$ ) and then weighed again. The root system of the seedlings separated from the substrate was placed into a measuring cylinder containing water to determine its volume (rsv). The accuracy of the volume measurement was $\pm 0.5 \mathrm{~cm}^{3}$ for pine and spruce throughout the growing period and for oak and beech on the first four dates, and $\pm 2.5 \mathrm{~cm}^{3}$ on the remaining dates. After obtaining the measurements, bulk density (bd) was determined based on the actual volume occupied by the substrate in the tray cell, calculated from the difference between the theoretical volume of cells, the root volume (rsv), and the volume not occupied by the substrate. The measurements were taken according to the method proposed by Cannavo et al. (2011) and Cannavo and Michel (2013). During the study, a total of 192 substrate samples were analyzed. The solid phase density was measured after obtaining the substrate samples. From the density of the solid phase and the bulk density of the dry substrate in the cell with undisturbed structure, the total porosity of the substrate (tp) and subsequently the water capacity of the substrate (wc) and air capacity (ac) were calculated in percent of cell volume (Niedziela and Nelson 1992; Caron et al. 2007). The standard methodology described 


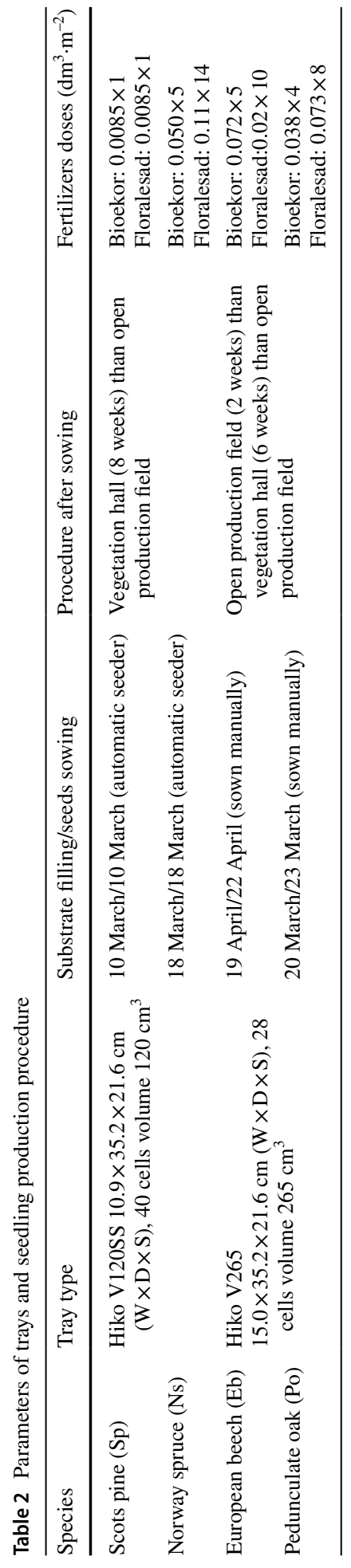


Table 3 Results of the one-way analysis of variance of the physicomechanical parameters of peat substrate in terms of the date of collection for analysis

\begin{tabular}{|c|c|c|c|c|}
\hline \multirow[t]{3}{*}{$\begin{array}{l}\text { Measured param- } \\
\text { eters }\end{array}$} & \multicolumn{4}{|c|}{$\begin{array}{l}12 \text { measurement dates (at 2-week intervals) from } 15 \text { May to } 16 \text { October. First meas- } \\
\text { urement for: Sp-66 DAS; Ns-58 DAS, Eb-23 DAS; Po-52 DAS }\end{array}$} \\
\hline & Scots pine $(\mathrm{Sp})$ & Norway spruce (Ns) & European beech $(\mathrm{Eb})$ & Pedunculate oak (Po) \\
\hline & mean $\pm S D$ & mean $\pm \mathrm{SD}$ & mean \pm SD & mean \pm SD \\
\hline tp $(\%)$ & $92.73 \pm 0.55^{* *}$ & $93.25 \pm 0.64 * *$ & $93.75 \pm 0.67 *$ & $93.24 \pm 0.86^{* *}$ \\
\hline wc $(\%)$ & $66.41 \pm 4.82^{* *}$ & $67.36 \pm 4.54 * *$ & $58.92 \pm 3.95 * *$ & $59.58 \pm 4.20 * *$ \\
\hline ac $(\%)$ & $26.32 \pm 5.11^{* *}$ & $26.13 \pm 4.47 * *$ & $34.95 \pm 4.09 * *$ & $33.77 \pm 4.74 * *$ \\
\hline $\mathrm{bd}\left(\mathrm{g} \cdot \mathrm{cm}^{-3}\right)$ & $0.102 \pm 0.06^{* *}$ & $0.098 \pm 0.009 * *$ & $0.087 \pm 0.011^{* *}$ & $0.092 \pm 0.01 * *$ \\
\hline $\operatorname{sdw}(g)$ & $9.52 \pm 0.59 * *$ & $9.62 \pm 0.91 * *$ & $19.46 \pm 3.24 * *$ & $18.92 \pm 2.84 * *$ \\
\hline $\operatorname{co}(\mathrm{kPa})$ & $105.1 \pm 24.2 * *$ & $101.9 \pm 17.3^{* *}$ & $84.9 \pm 25.7 .1 * *$ & $131.3 \pm 21.7 * *$ \\
\hline $\operatorname{rsv}\left(\mathrm{cm}^{3}\right)$ & $2.31 \pm 1.37 * *$ & $2.49 \pm 1.27 * *$ & $3.02 \pm 1.74 * *$ & $9.02 \pm 3.18 * *$ \\
\hline
\end{tabular}

$D A S$ days after sowing, $t p$ total porosity, $w c$ water capacity, $a c$ air capacity, $b d$ bulk density, $s d w$ substrate dry weight in tray cells, co compactness, and $r s v$ root system volume

Species (differences significant at $p<0.05$ "**" and $p<0.01$ "***)

Table 4 Results of the oneway analysis of variance for the comparison of physicomechanical parameters of peat substrate in terms of species

\begin{tabular}{|c|c|c|c|c|c|c|c|}
\hline \multirow[t]{2}{*}{ Species } & \multicolumn{7}{|c|}{ Compared parameters } \\
\hline & tp & wc & ac & bd & sdw & co & rsv \\
\hline Sp versus Ns (V120SS) & $* *$ & ns & ns & $* *$ & ns & ns & $* *$ \\
\hline Eb versus Po (V265) & $* *$ & ns & ns & $* *$ & ns & $* *$ & $* *$ \\
\hline
\end{tabular}

Designations: as in Table 1

Significant differences were determined at $p<0.01$ "***

in the PN-EN 13,041 and PN-78/G-98016 standards was not applied for the determination of the substrate parameters in the actual growth conditions of the seedlings in a single tray cell (Paquet et al. 1993; Cook et al. 2004). The significance of the variability between the physical and mechanical parameters of the substrate collected on individual dates and between the samples taken for different species was determined using a one-way analysis of variance, whereas for illustrating the changes in the measured parameters with time, a regression analysis was performed. The calculations were made using the Statistica 11 software (StatSoft 2006).

\section{Results}

For all the physicomechanical parameters of the substrates, significant differences were observed between the mean values calculated on various dates (Table 3). Statistical differences were also found when comparing the total porosity (tp), bulk density (bd) and root system volume (rsv) of the seedlings between the same tray types and when comparing the compactness $c o$ values between the V265 trays with beech and oak seedlings (Table 4). The substrate dry weight (sdw) (Fig. 1a), bd (Fig. 1b), tp (Fig. 1c), and co (Fig. 1d) changed throughout the production season, and the value of these parameters 

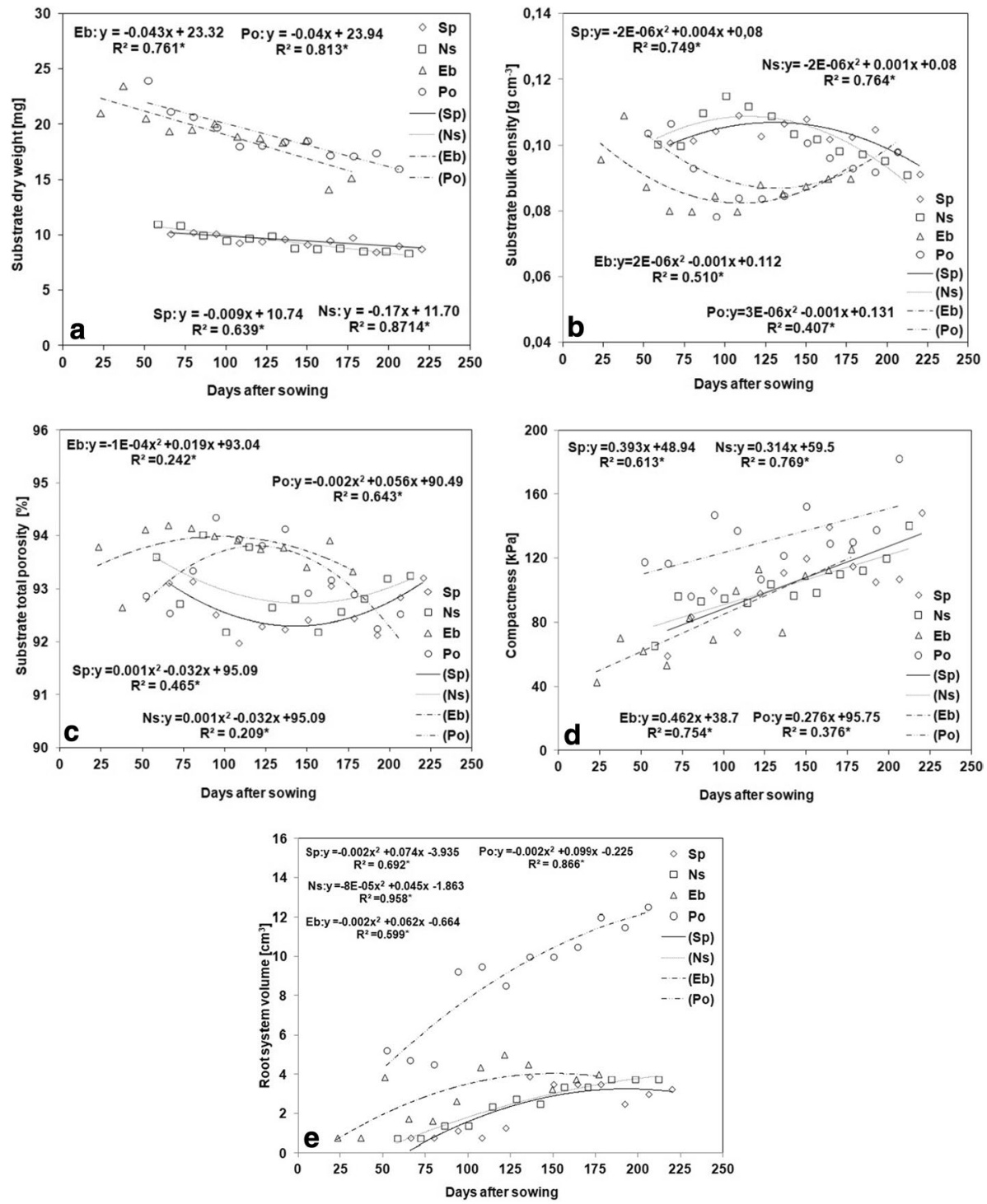

Fig. 1 Change in time: a substrate dry weight (sdw), b substrate bulk density (bd), c substrate total porosity (tp), and d substrate compactness (co), e root system volume (rsv) (*significant at $p<0.05$ )

depended significantly on the tray type. In addition to the obvious differences in the initial (sdw) value (Fig. 1a) in the V120SS and V265 trays, which were related to different cell volumes, a gradual reduction of (sdw) in the V265 cells was more apparent. For the trays with beech seedlings (capacity of cell $256 \mathrm{~cm}^{3}$ ), monitored for a total period of 168 days (12 dates $\times 14$ days), the loss of $s d w$ from the cells between the first and the last date of sampling was found to be on an average of $28.1 \%$, in the case of trays with oak $33.4 \%$, while for trays with smaller cells $\left(120 \mathrm{~cm}^{3}\right)$ with pine it was $13.5 \%$, and for spruce $24 \%$. The $b d$ values measured in tray cells (Fig. 1b) differed also between 
both tray types and seedlings. $S d w$ (Fig. 1a) decreased with time, along with an increase in root system volume $r s v$, which in turn was found to be reduced at the end of the monitoring period, particularly in the case of pine and beech (Fig. 1e). tp (Fig. 1c) was estimated to be the lowest for pine and spruce in the middle of the monitoring period, whereas in the case of beech and oak it was highest, but the course of changes in $t p$ with time was opposite to the course of changes in $b d$ (Fig. 1b). This difference can be related to the growth rate and structure of the root system of the seedlings and the difference in cell volume. With time, compactness co also increased (Fig. 1d), due to the increasing weight of the root system and stronger compaction of the substrate. Higher values of $c o$ were obtained for the substrate with oak seedlings; however, the course of changes and values of $c o$ in the V120SS trays with pine and spruce seedlings were similar. In the trays with beech seedlings, the increase of $c o$ in the monitoring period was highest at $193.8 \%$, for pine at $150.1 \%$, for spruce at $114.1 \%$, and for oak at $54.8 \%$. The substrate in the trays with pine and spruce seedlings (Fig. 2a) was characterized by a higher water capacity $w c$ and a lower air capacity $a c$ compared with the trays with beech and oak seedlings (Fig. 2b). A tendency of reduction of $a c$ and increase of $w c$ was found as time passed, particularly in the trays with beech and oak seedlings. In the initial period of seedling growth in the V265 trays, $a c$ was similar, and in certain cases, higher than the maximum limit value of $35 \%$, whereas $w c$ was close to the maximum limit value of 50\%. Contrary to the V265 trays, the values of $w c$ and $a c$ of the substrate in the V120SS trays remained within the optimum range. For the substrate in the V120SS trays, a higher value of $w c$ and a lower value of $a c$ were found than for the substrate in the V265 trays when analyzing the relationship between these parameters and the $b d$ of the substrate in tray cells (Fig. 3a). The range of values of the substrate $b d$ in the V120SS trays was different (higher) than in the V265 trays. Along with an increase in $b d$, $a c$ decreased and $w c$ increased, which was clearly seen in V120SS trays. The change in $w c$ and $a c$ was best explained by the quadratic regression equation (Fig. 3a). Quadratic regression equation also best explain change of compactness (co) measured with the cone penetrometer (Fig. 3b).
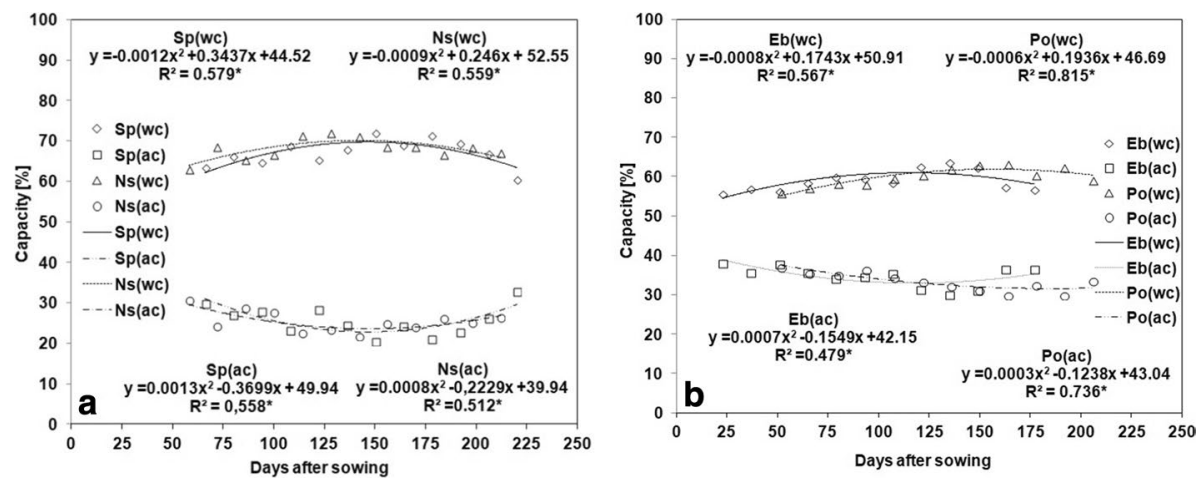

Fig. 2 Change in water capacity and air capacity of the substrate in the V120SS trays with pine and spruce seedlings (a) and in the V265 trays with beech and oak seedlings (b) (*significant at $p<0.05$ ) 

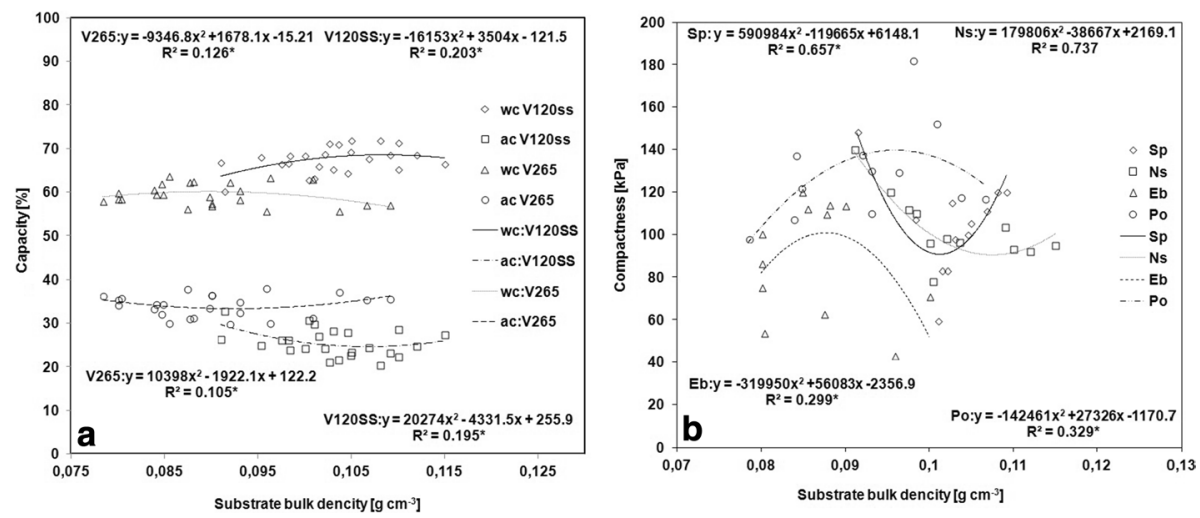

Fig. 3 Relationship between water capacity and air capacity (a) and substrate compactness measured with the cone penetrometer (b) and its bulk density in the cells of the V120SS and V265 tray (*significant at $p<0.05)$

\section{Discussion}

The present study demonstrated that substrate parameters in tray cells, where root systems of all the tested seedlings grew, changed within the production season. The amount of substrate decreased in both tray types with time, which indicated the reduced $s d w$. This phenomenon might have been caused by the substrate compaction and the related change in structure, which contributed to the leaching of the fine fractions outside of the tray and to peat decomposition. A greater loss was found in the V265 trays, whereas the change in $s d w$ was well reflected by regression equations. The weight loss, apart from cell volume in trays, might have also been influenced by the differences in the morphology of root system, which in the case of spruce, and particularly in pine, was strongly structured (Carlson and Endean 1976; Jackson et al. 2009; Kerloch and Michel 2015; Michel and Kerloch 2017), resulting in a slower leaching of substrate from trays. As indicated by Heiskanen (1995), the intensity of sprinkling irrigation and the structure of the foliage might also be of significance in this phenomenon. Change of $b d$ with time exhibited a curvilinear behavior, and for pine and spruce growing in the tray cells with lower volume (V120SS) $b d$ was found to be the highest in the middle of the measurement period (between July and August, for So it 156-170 Days After Sowing, for Ns: 148-162 DAS), whereas for beech and oak it was lowest (Eb:113-127 DAS, Po:142-156 DAS), which correlated with the curvilinear change of the volume occupied by the substrate in tray cells. Different behavior between these two groups of species can be related to the type of species and the volume of cells. This nonlinearity shall also be combined with the nonlinear change of $r s v$, which at the end of the monitoring period was reduced, particularly in the case of pine. A similar relationship of $r s v$ was noted by Allaire-Leung et al. (1999) for large-volume containers (500 $\mathrm{cm}^{3}$ ) in which Prunus $\times$ cistena sp. was grown. The authors concluded that the reduction of seedling growth at the end of the analyzed period may be associated with the change of climatic factors and the gradual entry of the seedlings into the resting phase (Welling and Palva 2006). Change of the root system volume $r s v$ furthermore influenced the change of $t p$, which in the case of pine and spruce (V120SS) was at the lowest level in the middle of the measurement period (between July and August), whereas for beech and oak (V265) it was the highest. An decrease of $t p$ in large trays in the initial production period, followed 
by its increase, was also indicated in the study of Allaire-Leung et al. (1999), who used 5 -L cylinders with a height of $20 \mathrm{~cm}$. The authors related this change to the initial decay and reorganization of substrate components, followed by the gradual growth of root system. Substrates with low $t p$ were typically associated with poorer plant growth (Allaire et al. 1996). According to the results of the present study, both $b d$ and $t p$ of substrate were typically within the recommended range; the value of $b d$ was $60-250 \mathrm{~kg} \cdot \mathrm{m}^{-3}$ and $t p$ was 85-95\% (Kipp et al. 2000). The $a c$ and $w c$ of substrate determined throughout the growing season exhibited a similar curvilinear behavior of change with time, which was independent of the type of container and seedling. The relatively low value of the determination factors of the regression models used for mapping the change of these parameters might have been caused by the high variability of the substrate placed in tray cells (lack of uniformity and mixing of peat with the remaining components), addition of uneven amount of substrate to individual tray cells, and the heterogeneous growth of seedlings (differences in the rates of germination and growth). A decrease of $a c$ and an increase of $w c$ with time have been observed by Jackson et al. (2009). This was particularly pronounced in the case of the substrate in the V265 trays with beech and oak seedlings and the V120SS trays with spruce seedlings. Similar results were reported by Allaire-Leung et al. (1999) in a 14-month experiment and Cannavo et al. (2011) in a 200-day experiment. Furthermore, in a study on a different substrate prepared with bark and pumice, a similar change of $a c$ and $w c$ was observed by Altland et al. (2011), which was indicated by the measurements taken after 48 and 382 days. In the present study, the results observed for the V120SS trays with pine and spruce seedlings indicated higher $w c$ and lower $a c$ compared to the V265 trays with oak and beech seedlings. In the initial period of seedling growth in the V265 trays, the $a c$ values were similar, and in certain cases, higher than the maximum limit value, which shall not exceed $35 \%$ or be lower than $15 \%$ according to Kipp et al. (2000), while according to Nkongolo and Caron (1999) or Cabrera et al. (2014) the maximum limit value might not be lower than $10 \%$. On the other hand, in the mentioned period wc was close to the minimum limit value, which was not lower than 50\% (Kipp et al. 2000; Cabrera et al. 2014) or higher than $80 \%$ (Kipp et al. 2000). Poor $w c$ may indicate the need to perform more frequent sprinkling irrigation in order to provide an appropriate amount of water for seed germination and seedling growth. In the V120SS trays, a clear difference in the capacity parameters was observed in the middle of the measurement period (between July and August, So: 156-170 DAS, Ns: 148-162 DAS) compared to the initial stage (May, Sp: 66 DAS; Ns: 58 DAS) and the end of the study (October So: 226-240 DAS, Ns: 218-232 DAS). Moreover, the difference in $a c$ and $w c$ as a function of $b d$ was also apparent for the V120SS and V265 trays. In the cells of the smaller volume trays (V120SS), for the same $b d$ a higher $w c$ and a lower $a c$ were obtained. Perhaps the substrate compositions should be selected individually for the tray type and the species, to more accurately meet the needs of the four species to improve grow-out success. A significant parameter for a rapid and simple measurement, which is not mentioned in the present study on tray nurseries but might be useful for studying peat or peat substrates (Boylan et al. 2011; Hayashi and Hayashi 2016), is co measured with the cone penetrometer. Co may be used to well characterize substrate properties, especially at the stage of tray filling, and it may even describe the changes in these properties occurring throughout the growing season. With the passage of time, substrate co increased in the trays, independent of the cell volume, and considerably higher values were found in the V265 tray cells with oak seedlings, which were influenced by the highly developed root system, characterized by large volume. With the increase of $b d, c o$ for pine and spruce increased and for beech and oak decreased, which complied with the measurement results obtained for organic materials (Stock and Downes 2008), as well 
as with the structure of root systems of individual species. It should be noted that apart from the amount of water contained in the substrate, the co volume was influenced by the degree of overgrowth of roots, which in turn resulted in the change of its structure and difficulty in performing measurement with the cone penetrometer, at the end of monitoring period.

\section{Conclusion}

By analyzing the results, the following conclusions were drawn:

- significant differences in substrate parameters occurred with time in the V120SS and V265 trays during the cultivation of the seedlings of all species;

- with time, dry weight of the substrate decreased and compactness increased in the tray cells;

- for all the species, the bulk density and total porosity of the substrates from trays had values within the recommended range, although porosity had values close to the recommended maximum and bulk density had minimum values;

- in certain periods of seedling growth, particularly in the V265 trays with beech and oak seedlings, water capacity was too low, whereas air capacity was too high, which in the case of cultivation of these species may result in the need to perform a frequent irrigation to ensure the optimum amount of water is available to the growing seedlings; and

- compactness measured with the cone penetrometer may be used to characterize substrate properties, especially at the stage of filling the trays with the substrate.

Acknowledgements This study was funded by The State Forest National Forest Holding, Grant Number ER 2717-4/14. Special thanks to the Staff of Rudy Raciborskie Forest Inspectorate and thanks to the Managers of Nędza Nursery Farm.

Open Access This article is licensed under a Creative Commons Attribution 4.0 International License, which permits use, sharing, adaptation, distribution and reproduction in any medium or format, as long as you give appropriate credit to the original author(s) and the source, provide a link to the Creative Commons licence, and indicate if changes were made. The images or other third party material in this article are included in the article's Creative Commons licence, unless indicated otherwise in a credit line to the material. If material is not included in the article's Creative Commons licence and your intended use is not permitted by statutory regulation or exceeds the permitted use, you will need to obtain permission directly from the copyright holder. To view a copy of this licence, visit http://creativecommons.org/licenses/by/4.0/.

\section{References}

Abad M, Fornes F, Carrion C, Noguera V (2005) Physical properties of various coconut coir dust compared to peat. Hort Sci 40:2138-2144

Argo WR (1998) Root medium physical properties. Hort Tech 8:481-485

Allaire-Leung SE, Caron J, Parent LE (1999) Changes in physical properties of peat substrates during plant growth. Can J Soil Sci Short Com 79:137-139

Allaire SE, Caron J, Duchesne I, Parent LÉ, Rioux JA (1996) Air-filled porosity, gas relative diffusivity, and tortuosity: indices of Prunus $\times$ cistena sp. growth in peat substrates. J Am Soc Hort Sci 121:236-242

Altland TE, Owen JO, Gabriel MZ (2011) Influence of pumice and plant roots on substrate physical properties. Hort Tech 21:554-557 
Bakry M, Lamhamedi MS, Caron J et al (2013) Changes in the physical properties of two Acacia compostbased growing media and their effects on carob (Ceratonia siliqua L.) seedling development. New For 44:827-847

Banach J, Skrzyszewska K, Świeboda L (2013) Substrate influences the height of one- and two-yearold seedlings of silver fir and European beech growing in polystyrene containers. For Res Papers $74: 117-125$

Beeson RC (2006) Relationship of plant growth and actual evapotranspiration to irrigation frequency based on management allowed deficits for container nursery stock. J Am Soc Hort Sci 131:140-148

Bilderback T, Warren S, Owen J, Albano JP (2005) Healthy substrates need physicals too! Hort Tech 15:747-751

Boylan N, Long M, Mathijssen FAJM (2011) In situ strength characterization of peat and organic soil using full-flow penetrometers. Can Geo J 48:1085-1099

Buck JS, Evans MR (2010) Physical properties of ground parboiled fresh rice hulls used as a horticultural root substrate. Hort Sci 45:643-649

Cabrera PI, Johnson JR (2014) Fundamentals of container media management: Part 1. Rutgers, NJSU FS, p 812

Cannavo P, Michel JC (2013) Peat particle size effects on spatial root distribution, and changes on hydraulic and aeration properties. Scient Hort 151:11-21

Cannavo P, Hafdhi H, Michel JC (2011) Impact of root growth on the physical properties of peat substrate under a constant water regimen. Hort Sci 46:1394-1399

Carlson LW, Endean F (1976) The effect of rooting volume and container configuration on the early growth of white spruce seedlings. Can J For Res 6:221-224

Caron J, Elric CE, Michel JC, Naasz R (2007) Physical properties of organic soils and growing media: Water and air storage and flow dynamics. In: Carter MR, Gregorich EG (eds) Soil sampling and methods of analysis, 2nd edn. CRC Press, Boca Raton, FL, pp 885-912

Cook A, Bilderback T, Lorscheider M (2004) Physical property measurements in container substrates: a field quantification strategy. SNA Res Conf 49:102-104

Dumroese RK, Monville ME, Pinto JR (2015) Using container weights to determine irrigation need a: a simple method. Native Plants J 16:67-71

Durło G, Jagiełło-Leńczuk K, Kormanek M, Małek S, Banach J (2018) Supplementary irrigation at container nursery. For Res Pap 79:13-21

Evans MR, Gachukia MM (2007) Physical properties of sphagnum peat- based root substrates amended with perlite or parboiled fresh rice hulls. Hort Tech 17:312-315

Fernandes C, Cora JE (2004) Bulk density and relationship air/water of horticulture substrate. Sci Agric 61:446-450

Ferree DC, Streeter JG, Yuncong Y (2004) Response of container-grown apple trees to soil compaction. Hort Sci 39:40-48

Fornes F, Belda RM (2019) Use of raw and acidified biochars as constituents of growth media for forest seedling production. New For 50:1063-1086

Goh KM, Haynes RJ (1976) Evaluation of potting media for commercial nursery production of containergrown plants. J Agri Res 20:363-370

Hayashi H, Hayashi T (2016) Estimating of undrained shear strength for peat using CPT. Australia Geoscience Society, Sydney, pp 1157-1160

Heiskanen J (1995) Water status of sphagnum peat and a peat -perlite mixture in containers subjected to irrigation regimes. Hort Sci 30:281-284

Heiskanen J, Rikala R (1998) Influence of different nursery container media on rooting of Scots pine and silver birch seedlings after transplanting. New For 16:27-42

Jackson BE, Wright RD, Seiler JR (2009) Changes in chemical and physical properties of pine tree substrate and pine bark during long-term nursery crop production. Hort Sci 44:791-799

Kaliniewicz Z, Tylek P (2018) Influence of scarification on the germination capacity of acorns harvested from uneven-aged stands of pedunculate oak (Quercus robur L.). For J 9:1-15

Kerloch E, Michel JC (2015) Pore tortuosity and wettability as main characteristics of the evolution of hydraulic properties of organic growing media during cultivation. Vadose Zone J 14:141-147

Kipp JA, Wever G, De Kreij C (2000) International substrate manual. Analysis, charakteristics and recommendations. PBK, Naaldwijk

Kormanek M, Głąb T, Banach J, Szewczyk G (2015a) Effects of soil bulk density on pedunculate oak Quercus petraea Liebl. seedlings. Eur J For Res 134:969-979

Kormanek M, Banach J, Sowa P (2015b) Effect of soil bulk density on forest tree seedlings. Int Agroph 29:67-74 
Landis TD (1990) The container tree nursery manual. Agric Handbook 674. Washington, DC. U.S. Department of Agriculture. Forest Service, pp 1-39

Landis TD, Dumroese RK, Haase DL (2010) The container tree nursery manual. Seedling processing storage and outplanting US Department of Agriculture Forest Service, pp 208

Lea- Cox JD, Ristvey AG, Ross D, Kantor GF (2009) Deployment of wireless sensor networks for irrigation and nutrient management in nursery and greenhouse operations. SNA Res Conf 54:28-34

Leciejewski P (2011) Irrigation of forest nurseries Library of the Forester. SITLiD Pub House, Warsaw (in Polish)

Luna T, Landis TD, Dumroese RK (2009) Containers. In: Smith J (ed) Nursery manual for native plants. A guide for tribal nurseries. US Department of Agriculture Forest Service, Washington, D.C., pp 95-111

Maciak F, Liwski S (1996) Exercises in peat science. SGGW Pub House, Warsaw (in Polish)

Mathers HM, Yeager TH, Case LT (2005) Improving irrigation water use in container nurseries. Hort Tech 15:8-12

Michel JC (2009) Physical properties of growing media: State of the art and future challenges. Ac Hort 3:65-71

Michel JC, Kerloch E (2017) Evolution of hydraulic properties and wettability of organic growing media during cultivation according to irrigation strategies. Sci Hort 217:28-35

Niedziela CE Jr, Nelson PV (1992) A rapid method for determining physical properties of undisturbed substrate. Hort Sci 27:1279-1280

Nkongolo NV, Caron J (1999) Bark particle sizes and the modification of the physical properties of peat substrates. Can J Soc Sci 79:111-116

Oleszczuk R, Bohne K, Szatylowicz J, Brandyk T, Gnatowski T (2003) Influence of load on shrinkage behaviour of peat soils. J Plant Nutr Soil Sci 166:220-224

Paquet JM, Caron J, Banton O (1993) In situ determination of the water desorption characteristics of peat substrates. Can J Soil Sci 73:329-339

PN-78/G 98016 (1978) Peat for gardening. Industry standard pp 4 (in Polish)

Ruter JM, Nad de Werken H (1991) Container design influences physical parameters of different media. Hort Tech 12:76-78

StatSoft (2006) Electronic Statistics Manual PL, Krakow, WEB: http://www.statsoft.pl/textbook/stathome. html

Stock O, Downes NK (2008) Effects of addition of organic matter on the penetration resistance of glacial till for the entire water tension range. Soil Till Res 99:191-201

Stowe DC, Lamhamedi MS, Carles S et al (2010) Managing irrigation to reduce nutrient leaching in containerized white spruce seedling production. New For 40:185-204

Strojny Z (2003) Substrate in container nursery production. Nursery 4:61-67 (in Polish)

Sun Q, Dumroese RK, Liu Y (2018) Container volume and subirrigation schedule influence Quercus variabilis seedling growth and nutrient status in the nursery and field. Scan J For Res 33:560-567

Szabla K, Pabian R (2003) Container nursery New technologies and techniques in forest nursery. State For Inf Centre, Warsaw (in Polish)

Tian N, Fang S, Yang W, Shang X, Fu X (2017) Influence of container type and growth medium on seedling growth and root morphology of Cyclocarya paliurus during nursery culture. For J 8:1-16

Welling A, Palva ET (2006) Molecular control of cold acclimation in trees. Phys Plant 127:167-181

Wesoły W, Hauke M (2009) Forest nursery from A to Z. State Forest Information Centre, Warsaw (in Polish)

Publisher's Note Springer Nature remains neutral with regard to jurisdictional claims in published maps and institutional affiliations. 